\title{
CULTURAL VALUE ORIENTATION OF SANDO BATU INDIGENOUS COMMUNITY
}

\author{
Eymal B. Demmalino, Muslim Salam, Hendra Sudirman, M. Saleh S. Ali* \\ Department of Agicultural Socio-Economics, Faculty of Agriculture, Hasanuddin University, \\ Makassar, Indonesia \\ *Corresponding author: saleh.assofie@gmail.com
}

Citation: Demmalino, E.B., Salam, M., Sudirman, H., Ali, M. Saleh S., 2017. Cultural Value Orientation of Sando Batu Indigenous Community. J. Asian Rur. Stud. 1(2): 152-161

\begin{abstract}
The focus of this research was to explore the Sando Batu indigenous community who live in harmony with nature. This study aimed to describe the cultural values orientation of the community. The study used a phenomenological approach by combining three methods of data collection, namely interviews, participant observation, and documentation. The theoretical framework used was Kluckhon value orientation which was widely used. The study was carry out on hamlet of Wala-wala of Pitu Riase Subdistrict of Sidenreng Rappang district where this community settle. The informants in this study consisted of seven people who were determinedby snowball sampling technique. The first informant was selected purposively namely the former head of the village and then the rest of informants were selected by snowball technique. The data were analyzed by using Interpretative Phenomenological Analysis (IPA). The results showed that the cultural values orientation of indigenous communities Sando Batu believes that life is difficult but must still be fought, the work is for survival, oriented to the future, harmony with nature, and relationship with one another was horizontal relationship.
\end{abstract}

Keywords: Indigenous community; Cultural value orientation; The Kluckhon framework; Sando Batu Community

\section{Introduction}

There are more than 300 million indigenous people in the world today. They are found in virtually every region, such as the Sámi peoples of Scandinavia, the Maya of Guatemala, numerous tribal groups in the Amazonian rainforest, the Dalits in the mountains of Southern India, the San and Kwei of Southern Africa, Aboriginal people in Australia, hundreds of Indigenous Peoples in Mexico, Central and South America, as well as in North America, and many others. These group of people have its own own distinct culture, language, history, and unique way of life. Despite these differences, Indigenous Peoples across the globe share some common values derived in from their beliefs and understanding about life which are part of and inseparable from the natural world (Mankiller, 2009).

Mankiller (2009) stated that indigenous people are not the only people who understand the interconnectedness of all living things. There are many thousands of people from different ethnic groups who care deeply about the environment and fight every day to protect the earth. The difference is that indigenous people have the benefit of being regularly reminded of their responsibilities to the land by stories and ceremonies. They remain close to the land, not only in the way they live, but in their 
hearts and in the way they view the world. Protecting the environment is not an intellectual exercise; it is a sacred duty."

In Indonesia, there are hundred indigenous comminities or tribe people can be found in Indonesia. This community is called masyarakat adat (costumary community) and some colled them as suku terasing (remote community). Some of them are Dani Tribe, Korowai and Bauzi Tribe in Papua, Togutil in Halmahera, Kubu and Anak Dalam in Jambi, Mentawai Tribe in Mentawai, Sakai in Sumatera, Polahi in Gorontalo, Kajang in Bulukumba, Baduy in Banten, Togutil Tribe in Maluku and so on. Most of these tribes settled in the mountain or protected forest area and lived with harmony with nature. Rasak (2013) stated that about 5,000,000 hectares of forest in Indonesia was still maintained its sustainability by indigenous people who live in the forest with their local wisdom to protect the forest.

One of the indigenous people in South Sulawesi which was still unexplored and touched by social scientist and rarely found in literature is Sando Batu community who live in Sidenreng Rappang (Sidrap), South Sulawesi. This community resides in areas that are encountered by five districts namely Sidrap District, Enrekang District, Tana Toraja District, Wajo District and Luwu District in Latimojong mountain region which is about 600-1000 meters above sea level. They mark their territory with stakes of stone (called Botto) and this territory is called the Ton Toga. This territory still exists today, and the community never leaves the area. They can not open forests outside the Ton Toga but they can pick up forest products such as rattan or resin in forests outside the Ton Toga line. Formally, the area claimed by the Sando Batu region is no longer belongs to them, because since 1984/1985 and 1997/1998 almost all of the areas have been designated by the government as protected forests (Hutan Lindung) and limited production forests (Hutan Produksi Terbatas). Therefore, they always feel threatened expelled to leave the ancestral land that they have been guarding since (Andang, 2009).

The life of the Sando Batu community is a life that blends with nature. They maintain their territory with knowledge and wisdom in which is much respect the nature. This can be seen from customary rules regarding the use of the nature, such as the rule that trees on the banks of the river must be guarded, river water must be kept from toxins (including Mattua', a fish poison made from the roots of trees), ban to enter $K e^{\prime} b o$ Tua (primary forest) marked with wooden bars. If one would like to enter this protected area should wear yellow clothing (Andang 2009).

Since not many studies have been done to explore the Sando Batu community, undertanding cultural value orientation of the Sando Batu community is an interesting study. Therefore this paper will explore the cultural value orientation of that community by using the Kluckhon framework. The framework has been used by many scholars in Indonesia to understand the cultural value orientation of a particular community. For instance, Jurniarsih (2007) used the framework to understand the change of value orientation of Sasak indigenous people in the Senggigi Tourism Area of Lombok Island; Priyadi (2008) in analyzing the cultural value orientation of traditional and modern Banyumas people; Sibuea (2007) on Cultural Values Orientation Batak Toba Overseas in Semarang; and Pamuji (2013) about the Orientation of Cultural Values in Kautamaning community.

As mentioned above, the Kluckhon framework was used as framework of the research. The Kluckhon framework has five basic essence of life that determines the 
value orientation of human culture, which is then used to find the views of Sando Batu communities. The Kluckhon framework is presented in Table 1.

Table 1. Kluckhon Framework of Human Cultural Value Orientation

\begin{tabular}{llll}
\hline \multirow{2}{*}{ Basics in Live } & \multicolumn{1}{c}{ Cultural Value Orientation } \\
\cline { 2 - 4 } Essence of Life & Life is bad & Life is good & $\begin{array}{l}\text { Trife is difficult but it has } \\
\text { to be fought }\end{array}$ \\
\hline Essence of Work & Work for Survive & $\begin{array}{l}\text { Work for Position and } \\
\text { Prestige }\end{array}$ & Work for higher prestige \\
\hline Human relation to time & Past Orientation & Present Orientation & Future Orientation \\
\hline Human relation to nature & Submit to nature & Harmony with nature & Exploit the nature \\
\hline Human relation to others & Vertical & Horizontal & Individual \\
\hline
\end{tabular}

*Modified from Pelly (Supsiolani, 2008)

\section{Method}

Epistemologically, this research used phenomenology approach. According to Creswell (1988), phenomenology has tried to describe the meaning of life experience of a number of people about a concept or phenomenon, which in this case is to describe the cultural value orientation of indigenous communities of Sando Batu. The study was conducted in Sidenreng Rappang (Sidrap) Distrcit, Pitu Riase Sub-district, Leppangeng village, precisely in Wala-Wala hamlet (see Map). The informants of this study consisted of seven people who were determined by snowball sampling technique, which was the former head of the village who was selected purposively as the first informant. The rest informants interviewed were Bandulu, Baddu, Kube, Bolong, Sudi, and Indar. A side from the seven informants, the researchers also got information from a number of Sando Batu residents. Data were collected by combining three data collection methods, namely, in-depth interview, participant observation, and documentation. Data were analyzed by using a tool developed by Smith, et al (2009) called Phenomenology Interpretative Analysis (PIA) that consists of six stages: reading and reading, initial noting, developing emergent themes, searching for connections across, moving the next cases, and looking for patterns across cases.

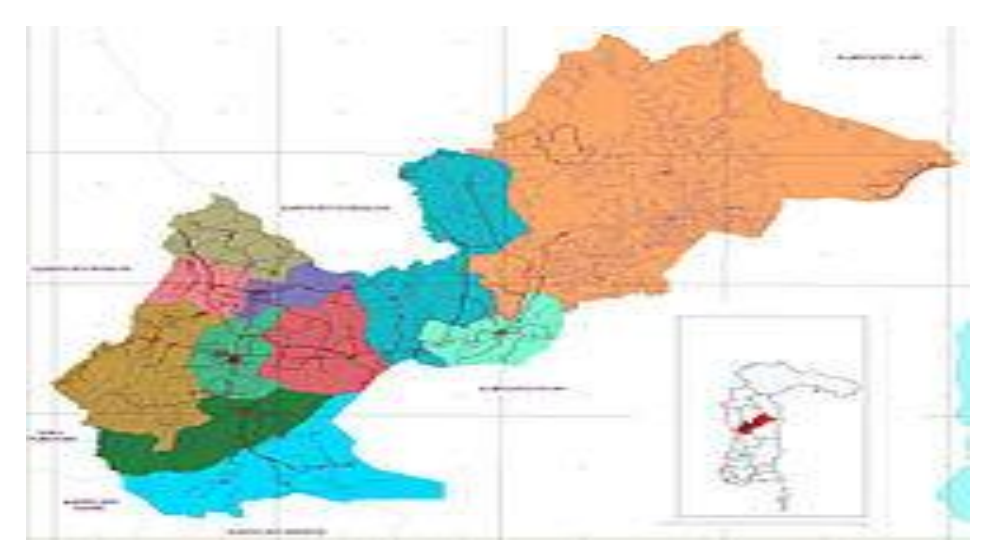

Figure 1. Map of location of the study (District of Sidenreng Rappang) 


\section{Results and Discussions}

\subsection{Socio-Economics and Cultural life of Sando Batu Indigenous Community \\ 3.1.1. History of Sando Batu indigenous community}

According to Andang (2009) Sando Batu indigenous community comes from Mount Tamaupa which is one of the mountains in the cluster of Latimojong Mountains. In his other writings along with Suwito and Takaka, Andang (2006) revealed that the indigenous community of Sando Batu is part of the Lumika Tribe. According to informants who obtained information from the story of their grandparents, stated that this community came from the kingdom of Batu as the oldest kingdom in Sidenreng Rappang Regency. The king of this kingdom is called Sando Batu King. The Sando Batu king ruled in two phases, namely pre-Islamic era and the period of Islam. Before the era of Islam, the Sando Batu King concurrently occupy the position as head of government and head of adat, but after the Islam accepted as religion of the community and the independent of Indonesia as a country, the role of governing of the community belong to Indonesian government system while the Sando Batu king is only taking care of customary (adat). After the collapse of the Batu kingdom, the Batu community in particular the Wala-Wala community remain obedient to Sando's teachings because and this community became known as the indigenous community of Sando Batu.

\subsubsection{Economic life}

The economy of the Sando Batu indigenous community basically is subsistence economy. Their economic activities are mainly on (1) farming and gardening, (2) making sago, (3) taking forest products, and (4) hunting and fishing.

\subsubsection{Leadership and social order}

The Sando Batu indigenous community has own leadership structure as follow:

a. Ada' Kampong

The Ada' Kampong is a customary institution that takes care of government affairs at kampong (hamlet) level. The person who occupies this position is called the kepala kampong (Head of Kampong). In carrying out his duties, Head of Kampong is supported by assistants called Rombongan Kampong.

\section{b. Ada' Sando}

The Ada' Sando is an institution of the Sando Batu that deals with culture and customs, including take care of medicines and diseases. The man/woman who play this role is known as Sando.

\section{c. Ada' Sorong}

The Ada' Sorong is an institution within this community that takes care of the management of natural resources within the restriction of Sando Batu community. The people in charge in this function is called Mado.

\section{d. Ada' Sara}

The Ada' Sara is a costumary institution that deals with religious affairs, especially Islam. Ada' Sara consists of three important positions, namely (1) Bilala who is in charge of calling for prayer (azan), (2) Katte who is in charge of reading 
the announcement or preaching before the congregation of Jumat prayer (Friday prayer), and (3) Imam whose main task is to lead prayer in every prayer time.

These four customary institutions govern the relations and social and economic behavior of Sando Batu community, which can create a stable social order. Criminal acts in the community are rarely found. They develop easily a mutual help among them to do something that need more help such as labor. They also have high trust and social care among the community members as well as with the outsiders of the community.

\subsubsection{Language}

According to Aziz (2013) the language of the indigenous communities of Sando Batu is the language of Lumika. Suwito et al. (2006) mentioned that the language of the Sando Batu community is Bahasa Batu (Batu language). The information from the informants were differences, some say that their language is Bahasa Pa'bulu (language of mountain people), some mention as Bahasa Lumika (Lumika language), and some call it as Bahasa Batu (Batu language). However, they are actually referring to the same language that the researchers concluded as the Batu language. The language of Pa'bulu and Lumika is a general term for the languages of the people who are living at the mountains of the Latimojong, which they called as the Lumika Tribe or known as Pa'bulu (mountain people). This is the same as Toraja language for the Toraja people, Duri language for Duri, and Tae language for the Luwu people, which all of whom live at the mountains of the Latimojong.

\subsubsection{Religion}

The Sando Batu people have practiced teaching of Islam since the days of the Batu Kingdom. According to Said (2014) they have embraced Islam since the 17th century AD. Despite having embraced Islam, but the original beliefs and culture of their ancestors are still so strong influencing their beliefs so they pracrice syncretism that is a combination of animist religion of his ancestors with Islam as they new religion. In fact they believe that there is no magical power or spirit that controls nature, such as forest spirits that control the forest, the spirit of land that controls the land, the spirit of water that controls the water, and the plant spirit that controls the plant.

\subsection{Cultural Value Orientation}

\subsubsection{Essence of Life}

There were three cultural values related to the essence of life. First, live was bad, but it has to be avoiding it by looking for ways to live well. Some suggested that the life of this world good and fun, so tend to live with riotous, without thinking about the future and their other life in the universe. But there has also lived in a world that thought it was bad, but man can afford to live in the world into good and pleasant (Koentjaraningrat, 2004). The indigenous community Sando Batu more look at life in the world is a gift of God that must be followed, and thankful for, so that in bad conditions one must still be accepted and fought to make life better. They believe that life will always towards better for humans' efforts. This view comes from their life experience that is always changing from time to time. This is, as stated by one informant that:

"It used to be the life of the people here are very difficult, our house used to be just a house Pangka-panka (home gardens), but Alhamdulillah (thanks God) 
after the people here plant cloves their revenue has increased, the house has changed as now (Bugis typical wooden house) ". (Interview: August 3, 2016).

If we look at the behaviour of Sando Batu people, they are not easy to give up to any difficulty in life, although they live in a fairly isolated area, difficult to get access to, difficult to get all the life necessities, the high cost of living, lack of facilities and infrastructure, and living with all-round limitations, they never give up but so easily accept the situation and change things for the better. Change begins from the economic sector in which they are working to get a better economic life. In the field of education, for instance, the children were sent to the city to get better education with hope their lives will be better than their parents. In terms of facilities and infrastructure, with assistance from the local government and private partie, they built roads, schools, windmills power electricity, and village health center. By these three changes, it has demonstrated that this community is always willing to improve their lives for the better.

\subsubsection{The essence of work}

There are three views of man toward the nature of the works. The first view is that man's work is substantially to enable it to live. The second view state that the essence of human work is to get a full standing honor in the community, and the third is a movement to produce more works (Kontjaraningrat, 2004). Based on the observations and interviews with the informants, the nature of work by the Sando Batu community was working to make ends meet. Before adopting a settle farming, their livelihoods were much more depending on nature by planting upland local rice variety, tapping the sap from lontara trees, looking for rattan and resins in the forest, fishing, and hunting.

At the present time, after they apply settle farming practice and growing commercial crops such coffee and clove, they are more intensive in cultivating their farms. This is because the agricultural land that they occupy is getting narrower due to an increasing number of people in the community.

Along with increased the price of cloves, the incomes of Sando Batu people have also increased and this make their need for new necessity is also increases. They become more consumer oriented and they prefer to buy rice and not more consuming maize and cassava as they did in the past. Fish no longer sought in the river, but prefer to buy it in the market. As a result, all of their income has been spent for consumption needs.

\subsubsection{The nature of human relations with time}

According Koentjaraningrat (2004) there are three possible values of a culture that developed in the community in relation to time. There is a culture that considers it important past time, so they often take guidance on the behavior of past events. There is a culture that considers the important of contemporary or present time, so they are not thinking of past and future times, what is important in today life. There is also a culture that more oriented towards the future, so life planning becomes a very important thing.

If these culture value orientations is plotted to the cultural values of Sando Batu indigenous community, then one can find that their cultural values are more future oriented. By interacting with outsiders the Sando Batu community gets a broader view about life. They understand that the food was not only comes from the forest or grow it 
by themselves, but it can also be obtained from others in a way to buy in market or barter. But later in the process, when they need knowledge and a solid foundation, they sent their children to school, although only just for primary school. In their view, the most important thing is they children have to able to read, to write and to count because this knowledge is required in life and commerce.

In further developments, with intensive interaction with external parties, and the influence of education and the deepening of the teachings of Islam, their way of life becomes more widely than ever before. The belief that life can not only be obtained by seeking, planting and trade but there are many other professions that can make money without having to work as hard as they clear the forest.

Orientation to the future of indigenous communities Sando Batu can also be seen from their habit of saving. These savings activities typically occur within the domestic sphere by way of income for subsistence harvest stored before the next harvest. Mostly used for educational expenses of children. In addition to the cost of living and education, they also saved money for urgent needs, such as to pay for treatment if there are family members who are sick or have an accident.

\subsubsection{The nature of human relationship with nature}

In relation human with nature, Koentjaraningrat (2004) states that there are three forms of cultural value. First, assumes that nature is something very powerful, so that human beings can only be surrendered without any lots that can be commercialized. Second, assume that human nature can be combated oblige to always trying to conquer nature. Last, cultural values that try to harmony with nature, so people tend to keep nature.

If based on the teachings and beliefs of their ancestors, evolving cultural values on Sando Batu indigenous community tend to submit to nature. They believe that nature has a powerful force that cannot be resisted by humans. Nature is seen have ability to give disaster to people in the form of landslides or drought. On the other side, nature is also seen as capable of giving life to man such as providing food and other necessities of life.

Grounded by it, then they respect nature by conducting certain rituals in an attempt to set up a good relationship with the spirits of the natural rulers. They believe that with good relations with nature, nature will always do good for them. This view indicates that the indigenous communities of Sando Batu tend to submit to nature.

However, when viewed from the laws of life and activities of everyday people, the communities of Sando Batu tend harmony with nature. They make use nature according to its carrying capacity. Management of natural resources that they practice is always with combination of conservation and preservation. The use of palm tree saps as brown sugar is an example that they take advantage of nature according to its carrying capacity.

Furthermore, when seen from the development view, the concept of submission to nature of the communities actually was in a transition phase from the people who are subject to the nature towards the society in harmony with nature. Most of their life is still dependent on nature, but there have been attempts to escape from such dependence. Nowadays, with the intensification farming, the correct cultivation practices, the use of 
fertilizers, pesticides, and the use of agricultural technologies to make their production becomes increasingly higher.

Sando Batu indigenous communities align with nature, not only be seen from the decrease of their dependence on nature, but also they keep the nature. Their customary rules explicitly contain prohibitions toward unconservation nature.

"Our indgenous custom asked us to protect and guard the land of our ancestors that where we live in now, because this land is at an elevation (upstream) makes the person who is below (downstream) much depend to person at upper level" (Bandulu, interview: August 7, 2016).

This statement claimed that the Sando Batu commnity protect their region as ancestor gift and not to harm others in the downstream.

\subsubsection{The nature of human relations with others}

According Koentjaraningrat (2004) there are three cultural values related to human relations. There are cultures that place great importance on the vertical relationship among one another, so it tends to be guided by the leading personalities, senior people or patrons. The other cultural orientation emphazises the importance of horizontal relations, which is try to keep a good relationship with one another. There is also a culture that presumes that man is not dependant on others in his life. This view is individualistic and high rate that the man should stand alone as much as.

But when seen from the development at this time, there is growing pattern of relationships that are tend to be individualists, as stated by the informant who was previously as Head of Kampong stated that:

"When I returned from Baruku (displacement), I distribute the land to community members where each family gets 2 hectares of land. In the past when I told them to plant corn and they planted corn. But nowday, if I asks them to plant corn they do not grow corn. They have their own desires. Now the community is already difficult to manage is not like the old days, people have changed "(Bandulu, interview: August 7, 2016).

The informant's statement shows the member of the community is no longer make decisions base on the decision made by the elders as an in the past. They tend to view that what is good and not good for him is determined by him. The above statement also shows that the pattern of vertical relations in indigenous communities SandoBatu tends to start to fade. This is, as stated by Manan (Pelly, 1994) that in the vertical relationship system, decisions is always made by the superiors (senior), but in the relations that are more personally the decision is made by an individu.

Furthermore, when viewed from the interaction between society, the relationship created tend to be horizontal, in which the decision applies to all those taken through a system of consultation (Sipulung), so that a decision does not always have to be guided by the figures customary, but rather is based on a collective decision involving all members of the community. The horizontal relationship can also be seen from the activities of mutual help such as in building water wheels, planting and construction of road, drainage, village health center and the construction of schools for their children.

Mutual help or cooperation in the economic field can be seen from their subsistence activities like farming, hunting, making sago, and fishing. In farming activities, every citizen of Sando Batu communities who are members of a group of neighborhood 
always open the fields together, grow together, and joint harvesting. In hunting, it never found a Sando Batu hunts alone, but they do it in groups of at least three people. The same is also in cutting sago, catching fish. In social relationship, the mutual help or cooperation occurs when a member of the community hit by disaster or hold a celebration such wedding. So from a series of such activities, it appears that the indigenous community Sando Batu has a high dependence on one another.

\section{Conclusion}

Based on the above explanation, it can be concluded that the cultural values orientation of Sando Batu indigenous communities believes that life is bad, but should still be fought, the work is for survival, oriented to the future, in the context of their economic activities tend to be in harmony with nature, the interaction with each other show that the relationship between them is horizontal.

If the the cultural values orientation of indigenous communities of Sando Batu is mapped on the template of the Kluckhon framework, the position of each of the basic essence of his life can be seen in Table 2.

Tabel 2. Cultural Value Orientation of Sando Batu Indigenous Community

\begin{tabular}{|c|c|c|c|}
\hline \multirow{2}{*}{ Basics in Life } & \multicolumn{3}{|c|}{ Cultural Value Orientation } \\
\hline & Conservative & Transition & Progresive \\
\hline The essence of life & & & $\begin{array}{l}\text { Life is difficult but } \\
\text { it must be fought }\end{array}$ \\
\hline The essence of work & $\begin{array}{l}\text { Life } \\
\text { sustainability }\end{array}$ & & \\
\hline Human relations with time & & & $\begin{array}{l}\text { Orientation to the } \\
\text { future }\end{array}$ \\
\hline Human relations with nature & & $\begin{array}{l}\text { In harmony with } \\
\text { nature }\end{array}$ & \\
\hline Human relationships with others & & Horizontal & \\
\hline
\end{tabular}

\section{References}

Andang, B. 2009. Mengintip Persoalan Masyarakat Adat Sando Batu. www.kombinasi.net/ mengintip- persoalan-masyarakat-adat-sando-batu/

Aziz, 2013. Ma 'pagolo' Ritual Adat Sando Batu yang Sakral Sebelum Puncak Acara Adat Masara. Suara Komunitas, Edisi 5 November.

Cresswel, J., 1998. Qualitatif Inquiry and Research Design: Choosing Among Five Traditions. Thousand Oaks: Sage

Jurniangsih N., 2007. Perubahan Orientasi Nilai Budaya Masyarakat Lokal Suku Sasak di Kawasan Wisata Sengigi Pulau Lombok (Change of Cultural Value Orientation of Local Community of Sasak in Senggigi Tourism Resort, Lombok Island). Jurnal Agroteks Vol. 17. No 3.

Koentjaraningrat, 2004. Kebudayaan, Mentalitas, dan Pembangunan. Jakarta: GramediaPustakaUtama.

Mankiller, W., 2009. Being Indigenous in the 21st Century. Cultural Survival Quarterly Magazine. 
Pamuji H., 2013. Orientasi Nilai Budaya dalam Kautamaninglaku Persaudaraan Setia Hati Terate. (Cultural Value Orientation in Kautamaning Setia Brotherhood. Depok: Univesitas Indonesia.

Pelly, U., and Menanti, A., 1994. Teori-teori Sosial Budaya (Socio-Cultural Theories). Jakarta: Proyek Pembunaan dan Peningkatan Mutu Tenaga Kependidikan Direktorat Jenderal Pendidikan Tinggi DEPDIKBUD.

Priyadi, S., 2008. Orientasi Nilai Budaya Banyumas: Antara Masyarakat Tradisional dan Masyarakat Modern. (Cultural Value Orientation of Banyumas: Between Traditional and Modern Community)JurnalHumaniora, Vol. 20, No. 2: 158-167

Rasak, S., 2013. Catatan Akhir Tahun AMAN Sulawesi Selatan.Kabar AMAN SulSel, Edisi 30 Desember 2013.

Salim, E., 2010. Ratusan Bangsa Merusak SatuBumi. Jakarta: Penerbit KOMPAS.

Sibuea, D., 2007. Orientasi Nilai Budaya Batak Toba Pada Pria Batak Toba Perantau di Semarang. Semarang: Univesrsitas Diponegoro.

Smith J. A. and Osborn, M., 2009. Interpretatif Phenomenological Analysis: Theory, Method and Research. London: Sage Publication Ltd.

Supsiloani. 2008. Analisa Nilai Budaya Masyarakat dan Kaitannya dengan Pembangunan Wilayah di Kecamatan Raya Kabupaten Simalungun. Medan: Universitas Sumatra Utara Press.

Suwito et al., 2006. Komunitas Adat Sando Batu dan Ton Toga di Kawasan Pegunungan Latimojong, Warta Tenure No. 3.

Wahana Lingkungan Hidup Indoensia. Outlok 2015. 